\title{
Analisis Biaya Produksi Dalam Meningkatkan Profitabilitas Perusahaan
}

Production Cost and Company's Profitability

\author{
Lukman Hidayat \\ Program Studi Manajemen, Sekolah Tinggi Ilmu Ekonomi Kesatuan \\ Bogor, Indonesia \\ E-Mail: looke1an@gmail.com \\ Suhandi Salim \\ Program Studi Manajemen, Sekolah Tinggi Ilmu Ekonomi Kesatuan \\ Bogor, Indonesia
}

Submitted: JUNI 2013

Accepted:

JULI 2013

\begin{abstract}
Production cost is important in determining selling price and as a basis for management decision making to decide whether products manufacturing will be continued or discontinued. In addition, production cost has influence on firm's profitability level; the smaller production cost, it will be inversely in proportion to its profitability.

The purpose of this study is to see how far the role of production cost affects profitability. By making some adjustments in production cost such as making efficiency, total number of the company's profitability can be increased compared to production cost which is still high. The research done at PT Sakti Kandakawana, located in Bogor.

The result shows that PT Sakti Kandakawana is still be able to improve profitability by making some corrections on productionn cost. The assumption is the same number of selling will get higher profitability if it's used lower production cost. Due to ineffective cost decreases more and more, the company has fund by efficiency without affecting products quality.

Based on the evaluation, it shows that the production cost applied so far is still wasteful caused by raw materials used are expensive. In addition, it appears that cost for overtime work is not effective campare to cost for regular work. Thereby, when more efficient production cost is determined, the company's profitability can be increased.
\end{abstract}

Keywords:Production Cost; Company's Profitability

\section{PENDAHULUAN}

Perhitungan harga pokok produksi tidak terlepas dari masalah biaya, karena harga pokok merupakan kumpulan dari biaya bahan baku, biaya tenaga kerja langsung dan biaya overhead pabrik yang semuanya perlu diperhatikan tingkat kegunaannya dalam suatu produk agar tercipta harga pokok produksi yang efektif. Biaya produksi dapat dinilai efektif dan efisien apabila produksi yang dihasilkan memiliki standar kuantitas dan kualitas yang berbanding dengan harga yang sesuai, sehingga biaya yang dikeluarkan dapat dikatakan tepat guna dan tidak mengandung adanya indikasi pemborosan. Maka pihak manajemen perlu melakukan evaluasi atas berbagai faktor biaya produksi sehingga dapat tercipta efisiensi dan menekan biaya standar yang tentu saja berpengaruh pada profitabilitas perusahaan.

Pada sebuah perusahaan dibutuhkan berbagai macam produk untuk proses produksi, yang tiap-tiap produk memiliki nilai-nilai yang cukup bersaing satu dengan yang lainnya, juga dapat digunakan sebagai alternatif bagi perusahaan untuk memperoleh laba yang lebih besar. Perhitungannnya dapat dilihat dari harga bahan baku dengan kuantitas yang dihasilkan tanpa mengurangi kualitasnya. Selain biaya bahan baku,

\section{JIMKES}

Jurnal Ilmiah Manajemen Kesatuan Vol. 1 No. 2, 2013 pp. $159-16$ STIE Kesatua 
Production Cost and Company's Profitability diperlukan juga biaya tenaga kerja. Contoh pemborosan pada biaya tenaga kerja misalnya menggunakan tenaga kerja yang berlebihan, bisa juga dengan penggunaan tarif overtime yang tentunya lebih mahal dibanding dengan biaya tenaga kerja langsung. Dan berbagai biaya yang dikeluarkan sejak dari bahan baku sampai dengan barang jadi merupakan informasi yang diperlukan dalam pengambilan keputusan.

Biaya produksi juga merupakan dasar yang memberikan perlindungan bagi perusahaan dari kemungkinan kerugian. Kerugian akan mengakibatkan suatu usaha tidak dapat tumbuh dan dapat mengakibatkan perusahaan harus menghentikan kegiatan bisnisnya. Untuk menghindari kerugian, salah satu cara adalah dengan berusaha memperoleh pendapatan yang paling tidak dapat menutup biaya produksi. Dengan demikian, sangat penting memperhitungkan biaya produksi dan menetapkan harga jual produk dengan tepat untuk memberikan perlindungan bagi perusahaan dari kerugian.

Penelitian ini dilakukan pada PT. Kandakawana Sakti yang berlokasi di Jalan Pembina Rawa Hawur, kampung Liobaru, Desa Leuwinutug, Citereup, Cibinong, Bogor. Perusahaan ini bergerak dalam bidang jasa pengecatan plastic part seperti part sepeda motor, mobil, dan lain-lain. Agar tercipta perhitungan yang lebih detail, maka digunakan satu jenis barang yang diproduksi sehingga perhitungan efisiensi biaya produksi menjadi lebih optimal, yaitu: cover protector motor yamaha warna black nylon.

Pada PT. Kandakawana sakti ini, biaya produksi merupakan penentu keberhasilan perusahaan dalam memproduksi barang. Apabila biaya produksi yang dipergunakan tidak tepat atau kurang optimal tentu akan mempengaruhi profitabilitas perusahaan karena terjadinya ketidakefisienan dalam produksi.Karena kebijakan akan efisiensi ini berpengaruh pada profitabilitas yang dihasilkan untuk perusahaan, maka permasalahan dalam penelitian fokus pada masalah analisis biaya produksi dalam meningkatkan profitabilitas perusahaan pada PT Kandakawana Sakti

Identifikasi permasalahan penelitian ini : (1) Bagaimana peranan efisiensi biaya produksi terhadap HPP pada PT. Kandakawana Sakti?; (2) Bagaimana peranan efisiensi biaya produksi dalam meningkatan profitabilitas perusahaan pada PT. Kandakawana Sakti?

Tujuan penelitian ini adalah untuk mengetahui peranan: (1) efisiensi biaya produksi terhadap HPP pada PT. Kandakawana Sakti; (2) efisiensi biaya produksi terhadap profitabilitas perusahaan pada PT. Kandakawana Sakti.

\section{TINJAUAN PUSTAKA}

\section{Biaya Produksi}

Biaya dapat digolongkan menjadi beberapa bagian, diantaranya adalah biaya produksi. Pengertian biaya produksi menurut Soemarso $(1996,295)$ : adalah biaya yang dibebankan dalam proses produksi selama suatu periode. Biaya ini terdiri dalam proses awal ditambah biaya pabrik. Termasuk dalam biaya-biaya yang dibebankan pada persediaan dalam proses akhir periode.

Pengertian biaya produksi Menurut Mulyadi $(1999,8)$ adalah pengorbanan sumber ekonomi, yang diukur dalam satuan uang, yang telah terjadi untuk tujuan tertentu.Sedangkan pengertian biaya produksi menurut Mas'ud Machfoedz $(1989,109)$ : merupakan biaya yang dipakai untuk menilai persediaan yang dicantumkan dalam laporan keuangan dan jumlahnya relatif lebih besar daripada jenis biaya lain yang selalu terjadi berulang-ulang dalam pola yang sama secara rutin.

Menurut L. Gayle Rayburn $(1995,27)$ "Production costs include the direct material, direct labor, and factory overhead incurred to produce a good or service".

Biaya produksi merupakan pengeluaran biaya terbesar bagi perusahaan manufaktur, oleh karena itu pihak manajemen harus melakukan suatu pengendalian biaya produksi dan mengoptimalkan pemanfaatannya secara rasional dan sistematis agar biaya produksi menjadi rasional dan efektif.

Biaya produksi dapat dikatakan efisien apabila pengeluaran biaya tersebut tidak terjadi suatu pemborosan serta mampu menghasilkan output produk dengan kuantitas dan kualitas yang baik, untuk itu diperlukan suatu usaha yang sistematis pada 
perusahaan dengan cara membandingkan prestasi kerja dengan rencana dan membuat tindakan tepat atas perbedaannya.

Dalam kegiatan produksi sebuah produk jadi, perusahaan harus mengukur biayabiaya yang sudah dikeluarkan sebagai dasar menentukan harga pokok produk, apabila terjadinya keterlambatan pengendalian akan mengakibatkan biaya meningkat dan profitabilitas menurun. Selain hal tersebut, perusahaan dalam melakukan suatu kegiatan produksinya memerlukan biaya guna mengolah bahan baku menjadi produk jadi. Biaya yang dikeluarkan tersebut akan diakumulasikan ke biaya produksi.

Jadi dapat disimpulkan biaya produksi adalah seluruh biaya yang dikeluarkan oleh perusahaan yang berhubungan dengan fungsi atau kegiatan dalam pengolahan bahan baku menjadi produk jadi yang mempunyai nilai jual.

Secara garis besar biaya produksi mempunyai elemen-elemen, yaitu biaya bahan baku langsung, biaya tenaga kerja langsung, dan biaya overhead pabrik.

1. Biaya bahan

Menurut prinsip akutansi yang lazim, semua biaya yang terjadi untuk memperoleh bahan baku dan untuk menempatkannya dalam keadaaan siap diolah, merupakan unsur harga pokok bahan baku yang dibeli. Harga pokok bahan baku terdiri dari harga beli yang tercantum dalam faktur dari penjual ditambah biaya angkutan, biayabiaya pembelian lain serta biaya yang dikeluarkan untuk menyiapkan bahan baku tersebut dalam keadaan siap diolah.

Biaya angkutan bahan baku dapat diperlakukan dengan dua cara : diperhitungkan sebagai tambahan harga pokok bahan baku yang dibeli atau diperlakukan sebagai unsur biaya overhead pabrik. Biaya angkutan diperhitungkan sebagai tambahan harga pokok bahan baku yang dibeli dengan dasar perbandingan kuantitas, perbandingan harga faktur, atau dengan tarif yang ditentukan dimuka.

Bahan baku yang disimpan di gudang berasal dari berbagai pembelian, yang kemungkinan besar mempunyai harga per satuan yang berbeda dari pembelian yang satu ke pembelian yang lain. Hal ini menimbulkan masalah pemilihan harga pokok per satuan bahan baku yang dipakai dalam produksi.

Dalam bagian ini diuraikan akutansi biaya dalam masalah-masalah pada bahan baku, jika dalam proses produksi terjadi sisa bahan (scrap materials), produk cacat (defective goods), dan produk rusak (spoiled goods).

a. Sisa bahan (scrap materials)

Bahan yang mengalami kerusakan dalam proses pengerjaaannya disebut sisa bahan. Perlakuan terhadap sisa bahan tergantung dari harga jual sisa bahan. Jika harga jual sisa bahannya rendah, biasanya tidak dilakukan pencatatan jumlah dan harga sampai saat penjualan. Tetapi jika harga jual sisa bahan tinggi, perlu dicatat jumlah dan harga jual sisa bahan dalam kartu persediaan pada saat sisa bahan diserahkan oleh bagian produksi kebagian gudang. Hasil penjualan sisa bahan diperlakukan sebagai pengurang biaya bahan baku yang dipakai dalam pesanan yang menghasilkan sisa bahan.

b. Produk rusak (spoiled goods)

Produk rusak adalah produk yang tidak memenuhi standar mutu yang telah ditetapkan, yang secara ekonomis tidak dapat diperbaiki menjadi produk yang baik. Produk rusak berbeda dengan sisa bahan karena sisa bahan merupakan bahan yang mengalami kerusakan dalam proses produksi, sehingga belum sempat menjadi produk, sedangkan produk rusak merupakan produk yang telah menyerap biaya bahan, biaya tenaga kerja dan biaya overhead pabrik.

Perlakuan terhadap produk rusak adalah tergantung dari sifat dan sebab terjadinya:

1. Jika produk rusak terjadi karena sulitnya pengerjaaan pesanan tertentu atau faktor luar biasa yang lain, maka harga pokok produk rusak dibebankan sebagai tambahan harga pokok produk yang baik dalam pesanan yang bersangkutan. 
Production Cost

and Company's

Profitability

\section{2}

2. Jika produk rusak merupakan hal yang normal terjadi dalam proses pengolahan produk, maka kerugian yang timbul sebagai akibat terjadinya produk rusak dibebankan kepada produksi secara keseluruhan, dengan cara memperhitungkan kerugian sebagai biaya overhead pabrik. Oleh karena itu, anggaran biaya overhead pabrik yang akan digunakan untuk menentukan tarif biaya overhead pabrik terdiri dari unsur-unsur berikut ini :

Biaya bahan penolong
Biaya tenaga kerja tak langsung
Biaya reparasi dan pemeliharaan
Biaya asuransi
Biaya overhead pabrik lain
Rugi produk rusak (hasil penjualan -
Harga Pokok produk rusak)
Biaya overhead pabrik yang dianggarkan

$\mathrm{Xxxx}$

$\mathrm{Xxxx}$

$\mathrm{Xxxx}$

$\mathrm{Xxxx}$

$\mathrm{Xxxx}$

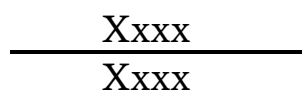

c. Produk cacat (defective goods)

Produk cacat adalah produk yang tidak memenuhi standar mutu yang telah ditentukan tetapi dengan mengeluarkan biaya pengerjaan kembali untuk memperbaikinya, produk tersebut secara ekonomis dapat disempurnakan lagi menjadi produk jadi yang baik.

Masalah yang timbul dalam produk cacat adalah bagaimana memperlakukan biaya tambahan untuk pengerjaan kembali (rework cost) produk cacat. Perlakuan terhadap biaya pengerjaan kembali produk cacat adalah mirip dengan yang telah dibicarakan dalam produk rusak (spoiled goods).

Jika produk cacat bukan merupakan hal yang biasa terjadi dalam proses produksi, tetapi karena karakteristik pengerjaan pesanan tertentu, maka biaya pengerjaan kembali produk cacat dapat dibebankan sebagai tambahan biaya produksi pesanan yang bersangkutan.

Jika produk cacat merupakan hal yang biasa terjadi dalam proses pengerjaan produk, maka biaya pengerjaan kembali dapat dibebankan kepada seluruh produk dengan cara memperhitungkan biaya pengerjaan kembali tersebut kedalam tarif biaya overhead pabrik.

2. Biaya tenaga kerja langsung

Menurut Supriyono $(1999,20)$ biaya tenaga kerja langsung adalah balas jasa yang diberikan kepada karyawan pabrik yang manfaatnya dapat didefinisikan atau diikuti jejaknya pada produk yang dihasilkan perusahaan".

Jadi biaya tenaga kerja langsung adalah karyawan yang dikerahkan untuk mengubah bahan langsung menjadi barang jadi. Biaya ini meliputi gaji para karyawan yang dapat dibebankan kepada produk tertentu.

3. Biaya overhead pabrik

Pengertian biaya overhead pabrik menurut Supriyono $(1999,21)$ adalah produksi selain biaya bahan baku dan biaya tenaga kerja langsung yang elemennya dapat digolongkan ke dalam biaya bahan penolong, biaya tenaga kerja tidak langsung, penyusutan dan amortisasi aktiva tetap pabrik, pemeliharaan aktiva tetap pabrik, biaya listrik, biaya asuransi dan biaya overhead lain.

Dari definisi diatas dapat diambil simpulan bahwa biaya Overhead Pabrik adalah komponen biaya selain biaya bahan baku dan biaya tenaga kerja langsung yang sulit didefinisikan tetapi menunjang proses produksi suatu perusahaan.

Berdasarkan penjelasan diatas juga dapat disimpulkan bahwa ketiga unsur harga pokok produksi merupakan suatu kesatuan yang tidak dapat dipisahkan, karena antara biaya yang satu dengan yang lainnya terdapat saling keterkaitan.

Pengertian pengendalian biaya produksi menurut Hansen dan Mowen $(2000,276)$ "Control is looking backward, determining what actually happened and comparing it with the previously planned outcomes". 
Pengertian pengendalian biaya produksi menurut Stoner, Freeman, dan Gilbert $(1996,248)$ "Biaya produksi adalah proses untuk memastikan bahwa aktivitas sebenarnya sesuai dengan aktivitas yang direncanakan".

Berdasarkan pengertian diatas, dapat disimpulkan bahwa pengendalian biaya adalah perbandingan kinerja aktual dan kinerja standar, selisih dianalisis sehingga diketahui penyebabnya agar dapat diambil tindakan yang tepat.

\section{Profitabilitas Perusahaan}

Profitabilitas merupakan hasil akhir bersih dari berbagai kebijakan dan keputusan manajemen serta memberikan jawaban akhir tentang efektivitas pengelolaan perusahaan.Setiap perusahaan harus dapat memahami bagaimana kemampuan perusahaan dalam menghasilkan laba yang diperoleh, kegiatan yang terjadi dalam perusahaan, kegiatan yang terjadi dalam perusahaan, karenanya kegiatan harus diringi dengan tanggung jawab yang tinggi dari perusahaan karena perusahaan memegang kendali.

Pengertian profitabilitas menurut Sundjaja (2003) adalah kemampuan perusahaan dalam menghasilkan laba, dilihat dari hubungan antara pendapatan dan biaya yang dihasilkan dari penggunaan aktiva perusahaan baik aktiva tetap maupun aktiva lancar dalam kegiatan yang produktif. Laba perusahaan dapat ditingkatkan melalui peningkatan pendapatan dan pengurangan biaya. Laba yang diperoleh perusahaan akan meningkatkan dan mengembangkan usaha. Perusahaan dapat memperoleh keuntungan lebih besar apabila perusahaan dapat memperluas pangsa pasar untuk produknya".

Sedangkan menurut Agus Sartono $(2001,122)$ "Kemampulabaan adalah kemampuan perusahaan memperoleh laba. Ukuran profitabilitas yang paling penting adalah laba bersih".Dapat diartikan bahwa pada dasarnya kemampulabaan menggambarkan kemampuan perusahaan untuk mendapatkan laba yang diharapkan. Pada umumnya modal perusahaan dapat berasal dari pemilik perusahaan dan dari para kreditur.

\section{Kerangka Pemikiran Konseptual}

Biaya standar dapat digunakan sebagai alat pengendalian dan sebagai dasar tolak ukur efisiensi suatu perusahaan. Hal ini dimaksudkan sebagai alat perbandingan guna mengevaluasi pelaksanaan kinerja perusahaan secara objektif, sehingga perusahaan dapat mengendalikan biaya serta mengukur efisiensi.

Berdasarkan uraian diatas, maka kerangka berpikir mengenai pengaruh penerapan efisiensi biaya produksi terhadap profitabilitas perusahaan dituangkan pada gambar berikut :

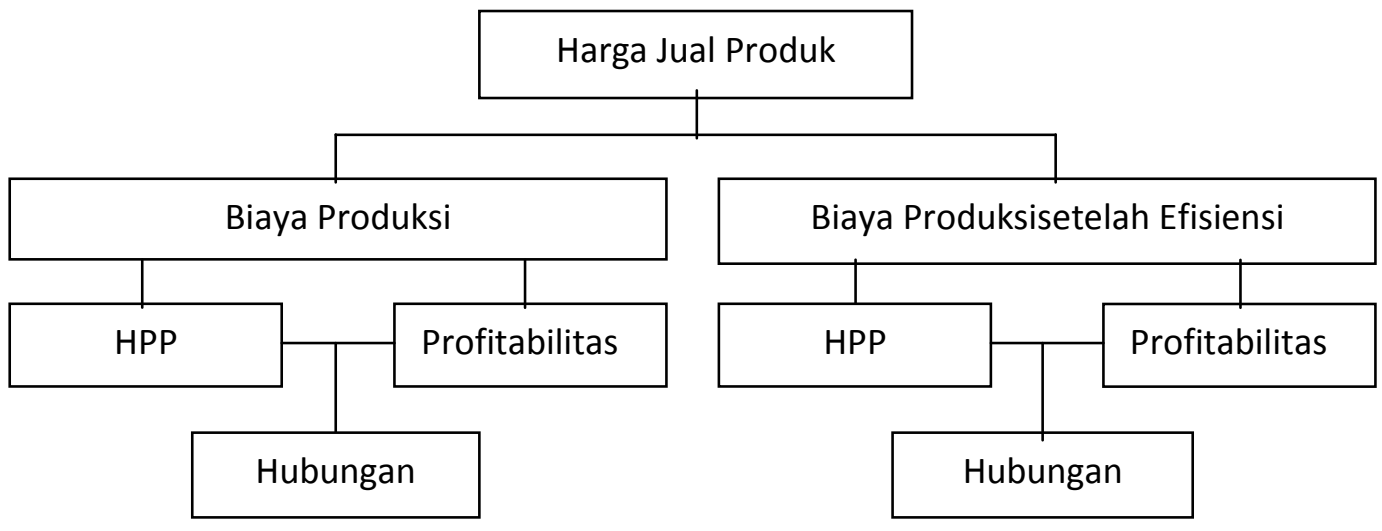

\section{Hipotesis}

Gambar 1. Kerangka Pemikiran Penelitian

Dari uraian diatas dapat diambil simpulan melalui hipotesis penelitian yaitu :

1. Kebijakan penerapan efisiensi biaya produksi diduga mengurangi HPP.

2. Kebijakan penerapan efisiensi biaya produksi diduga meningkatkan profitabilitas perusahaan. 
Production Cost and Company's Profitability

164

\section{METODOLOGI PENELITIAN}

Observasi penelitian ini dilakukan pada PT. Kandakawana Sakti yang berada di di J1. Pembina Rawa Haur, Kampung Liobaru, Desa Leuwinutug, Citereup, Cibinong. Dengan objek penelitian mengenai penerapan biaya produksi dengan sebuah standar biaya yang baru dengan efisiensi didalamnya. Kemudian membandingkannya dengan standar biaya pabrik dan menganalisis perbedaan pada saat penerapannya terhadap profitabilitas sebuah perusahaan.

\section{Operasionalisasi Variabel}

Ada dua variabel yang digunakan dalam penelitian ini, satu variabel bebas (Analisis efisiensi biaya produksi) dan satu variabel terkait (Pengaruh terhadap profitabilitas). Dari dua variabel yang digunakan pada penelitian ini ditentukan masing-masing sebagai berikut :

Tabel 1Operasionalisasi Variabel

\begin{tabular}{|c|l|c|}
\hline Variabel/Sub Variabel & \multicolumn{1}{|c|}{ Indikator } & Skala/Ukuran \\
\hline Biaya Produksi & $\bullet$ Biaya Standar Produksi Perusahaan & $\begin{array}{l}\text { Ratio } \\
\text { Ratio }\end{array}$ \\
\hline Profitabilitas & $\bullet$ HPP dengan Biaya standar & Ratio \\
Perusahaan & $\bullet$ HPP dengan Biaya Efisiensi & Ratio \\
\hline
\end{tabular}

Adapun jenis dan sumber data yang diperoleh berupa data kualitatif dan data kuantitatif. Prosedur pengumpulannya dapat dibedakan menjadi : (1) Data primer dan (2) Data sekunder. Untuk menganalisis peranan dari efisiensi biaya produksi PT. Kandakawana Sakti dalam meningkatkan profitabilitasnya menggunakan analisis : (1) selisih biaya (varians); (2) mengukur profitabilitas perusahaan.

Untuk mengukur kemampulabaan dapat digunakan rasio GPM, OPM, dan NPM karena rasio ini menunjukan besar persentase pendapatan bersih dari setiap penjualan. Semakin besar rasionya semakin baik, karena dianggap kemampuan perusahaan mendapatkan laba tinggi. Berikut adalah cara menghitung profitabilitas perusahaan dengan menggunakan rasio :

$\begin{array}{lll}\text { Rumus GPM } & = & \frac{\text { Gross Profit }}{\text { Sales }} \\ \text { Rumus OPM } & = & \underline{\text { EBIT }} \\ & & \text { Sales } \\ \text { Rumus NPM } & = & \underline{\text { EAT }} \\ & \text { Sales }\end{array}$

\section{HASIL DAN PEMBAHASAN}

\section{Peranan Efisiensi Biaya Produksi Dalam Meningkatkan Profitabilitas Perusahaan}

Perusahaan yang melakukan efisiensi biaya tentu bertujuan untuk meningkatkan labanya. Semakin tinggi laba perusahaan, maka profitabilitas yang diperoleh semakin tinggi. Ini akan berpengaruh pada citra perusahaan. Pada PT. Kandakawana Sakti ini, akan dianalisis bagaimana hubungan antara penerapan efisiensi biaya terhadap profitabilitas perusahaan dengan membandingkan laporan laba rugi perusahaan dengan menggunakan biaya standar dan biaya setelah efisiensi. Dengan biaya yang telah dihitung diatas pada saat perhitungan HPP. Dan penjualan yang dianggap sama yaitu pada tahun 2008 sebesar Rp. 2,304,000,000. 
Berikut adalah tabel perbandingan laba rugi dengan penjualan yang sama serta HPP dari biaya standar dan setelah efisiensi biaya pada tahun 2008 :

Tabel 2 Perbandingan Laba Rugi Perusahaan

\begin{tabular}{lrrr}
\hline \multicolumn{1}{c}{ Keterangan } & \multicolumn{1}{c}{ Biaya Standar } & Biaya Setelah Efisiensi & \multicolumn{1}{c}{ Selisih } \\
\hline Penjualan Bersih & $2,304,000,000$ & $2,304,000,000$ & \\
Harga Pokok Penjualan & $(1,547,618,593)$ & $(1,461,214,752)$ & $(86,403,841)$ \\
Laba Kotor & $756,381,407$ & $842,785,248$ & $(86,403,841)$ \\
Biaya penjualan, Adm. Umum & $(58,800,000)$ & $(58,800,000)$ & \\
Laba Operasi & $697,581,407$ & $783,985,248$ & $(86,403,841)$ \\
Biaya Bunga 15\% & $(104,637,211)$ & $(117,597,787)$ & $12,960,576$ \\
Laba Sebelum Pajak & $592,944,196$ & $666,387,461$ & $(73,443,265)$ \\
Pajak 20\% & $(118,588,839)$ & $(133,277,492)$ & $14,688,653$ \\
Laba Setelah Pajak & $474,355,357$ & $33,109,969$ & $(58,754,612)$ \\
Deviden & $474,355,357$ & $533,109,969$ & $(58,754,612)$ \\
\hline
\end{tabular}

Keterangan :

1. Penjualan bersih pada kedua laporan laba rugi diasumsikan sama, baik laporan laba rugi sebelum penerapan efisiensi biaya produksi maupun laporan laba rugi setelah penerapan laba rugi setelah penerapan efisiensi biaya produksi yaitu sebesar Rp. 2,304,000,000 selama tahun 2008.

2. Perubahan harga pokok penjualan pada tahun 2008 sebesar Rp. 1,547,618,593 pada laporan laba rugi standar dan berubah menjadi Rp. 1,461,214,752, mengalami perbedaan sebesar Rp. 86,403,841 selama satu tahun, disebabkan karena perubahan HPP yang terjadi akibat penerapan efisiensi biaya produksi yang dilakukan perusahaan.

3. Kedua perubahan diatas mempengaruhi laba kotor yang pada laporan laba rugi sebelum efisiensi biaya sebesar Rp. 756,381,407 menjadi 842,785,248. Disini terdapat selisih sebesar Rp. 86,403,841. Perubahan ini diakibatkan karena perubahan HPP.

4. Biaya Penjualan, Adm. Umum dan penyusutan pada kedua laporan laba rugi tidak berubah, baik laporan laba rugi sebelum penerapan efisiensi biaya produksi maupun laporan laba rugi setelah penerapan laba rugi setelah penerapan efisiensi biaya produksi sebesar Rp. 58,800,000.

5. Pada laba operasi terdapat perbedaan laba operasi pada laporan laba rugi dengan biaya produksi standar sebesar Rp. 697,581,407 dan pada laporan laba rugi setelah penerapan efisiensi biaya sebesar Rp. 783,985,248. Disini terdapat selisih sebesar Rp. $86,403,841$. Perubahan ini diakibatkan karena perubahan HPP.

6. Pada biaya bunga terdapat perbedaan laba operasi pada laporan laba rugi dengan biaya produksi standar dengan bunga sebesar 15\% per tahun maka jumlah beban bunga adalah sebesar Rp. 104,637,211 dan pada laporan laba rugi setelah penerapan efisiensi biaya sebesar Rp. 117,597,787. Disini terdapat perbedaan pengeluaran sebesar Rp. 12,960,576. Perbedaan ini mengalami kenaikan dikarenakan laba kotor pada laporan laba rugi setelah penerapan efisiensi biaya yang lebih tinggi daripada laba kotor pada laporan laba rugi dengan biaya standar.

7. Pada laba sebelum pajak terdapat perbedaan laba operasi pada laporan laba rugi dengan biaya produksi standar sebesar Rp. 592,944,196 dan pada laporan laba rugi setelah penerapan efisiensi biaya sebesar Rp. 666,387,461. Disini terdapat perbedaan keuntungan sebesar Rp. 73,443,265.

8. Pada beban pajak sebesar $20 \%$ per tahun dapat dilihat perbedaan pada laporan laba rugi dengan biaya produksi standar sebesar Rp. 118,588,839 dan pada laporan laba rugi setelah penerapan efisiensi biaya sebesar Rp. 133,277,492. Disini terdapat perbedaan keuntungan sebesar Rp. 14,688,653.

9. Pada laba setelah pajak terdapat perbedaan pada laporan laba rugi dengan biaya produksi standar sebesar Rp. 474,355,357 dan pada laporan laba rugi setelah
Production Cost and Company's Profitability 
Production Cost and Company's Profitability penerapan efisiensi biaya sebesar Rp. 533,109,969. Disini terdapat perbedaan keuntungan sebesar Rp. 58,754,612. Ini merupakan laba yang mengalami kenaikan selama satu tahun produksi apabila dilakukan penerapan efisiensi biaya produksi pada cover protector motor Yamaha warna black nylon.

Dari perhitungan selisih laba rugi antara pemakaian biaya bahan baku standar dan biaya bahan baku setelah efisiensi, digunakan data historis perusahaan untuk menganalisis perubahan tingkat penjualan perusahaan dari tahun 2003-2008 dengan pemakaian bahan baku menggunakan biaya bahan baku standar. Berikut adalah data historis yang di miliki perusahaan sejak tahun 2003 :

Tabel 3 Perubahan Penjualan Perusahaan

\begin{tabular}{cccc}
\hline Tahun & Penjualan & Selisih & Peningkatan \\
\hline 2003 & $1,183,200,000$ & & \\
2004 & $1,392,000,000$ & $208,800,000$ & $17.65 \%$ \\
2005 & $1,656,000,000$ & $264,000,000$ & $18.97 \%$ \\
2006 & $1,860,000,000$ & $204,000,000$ & $12.32 \%$ \\
2007 & $2,083,200,000$ & $223,200,000$ & $12.00 \%$ \\
2008 & $2,304,000,000$ & $220,800,000$ & $10.60 \%$ \\
\hline \multicolumn{5}{c}{ Rata-rata peningkatan } & $14.31 \%$ \\
\hline
\end{tabular}

Selanjutnya kita dapat menghitung perubahan HPP perusahaan, dengan menggunakan data historis perusahaan untuk menganalisis perubahan tingkat HPP perusahaan dari tahun 2003-2008 dengan pemakaian bahan baku menggunakan biaya bahan baku standar.

Tabel 4Perubahan HPP Perusahaan

\begin{tabular}{crcc}
\hline Tahun & \multicolumn{1}{c}{ HPP } & Selisih & Peningkatan \\
\hline 2003 & $796,753,662$ & & \\
2004 & $947,704,683$ & $150,951,021$ & $18.95 \%$ \\
2005 & $1,112,781,141$ & $165,076,458$ & $17.42 \%$ \\
2006 & $1,220,962,407$ & $108,181,266$ & $9.72 \%$ \\
2007 & $1,392,559,430$ & $171,597,023$ & $14.05 \%$ \\
2008 & $1,547,618,593$ & $155,059,163$ & $11.13 \%$ \\
\hline \multicolumn{5}{c}{ Rata-rata peningkatan } & $14.26 \%$ \\
\hline
\end{tabular}

Setelah dilakukan pengujian data historis perusahaan diatas, dibuat asumsi jumlah biaya pada tahun berikutnya dengan dua buah kemungkinan, yakni dengan menggunakan biaya standar dan biaya setelah efisiensi. Berikut adalah asumsi tabel HPP pada tahun yang akan datang dengan menggunakan dua kemungkinan tersebut :

Tabel 5Asumsi Laba/Rugi perusahaan

\begin{tabular}{ccccc}
\hline Tahun & Penjualan & $\begin{array}{c}\text { Laba Dengan } \\
\text { Biaya Standar }\end{array}$ & $\begin{array}{c}\text { Laba dengan Biaya } \\
\text { Setelah Efisiensi }\end{array}$ & Selisih \\
\hline 2008 & $2,304,000,000$ & $474,355,357$ & $533,109,969$ & $58,754,612$ \\
2009 & $2,633,702,400$ & $518,361,737$ & $586,833,800$ & $68,472,063$ \\
2010 & $3,010,585,213$ & $743,646,923$ & $813,454,192$ & $69,807,269$ \\
2011 & $3,441,399,957$ & $1,004,052,743$ & $1,075,221,254$ & $71,168,510$ \\
2012 & $3,933,864,291$ & $1,304,651,299$ & $1,377,207,595$ & $72,556,296$ \\
\hline
\end{tabular}

Sehubungan dengan perbedaan dua buah biaya diatas yaitu biaya standar dan biaya setelah penerapan efisiensi biaya, untuk mengukur besarnya GPM, NPM dan OPM di 
PT. Kandakawana Sakti berdasarkan asumsi tren penjualan dan kenaikan HPP yang telah di bahas di atas dengan kedua jenis biaya tersebut.

Berikut adalah data historis GPM yang di miliki perusahaan sejak tahun 2003 :

Tabel 6Perubahan Laba/Rugi Perusahaan

Production Cost

and Company's

Profitability

\begin{tabular}{cccccr}
\hline Tahun & Penjualan & HPP & GPM & OPM & NPM \\
\hline 2003 & $1,183,200,000$ & $796,753,662$ & 0.33 & 0.29 & 0.20 \\
2004 & $1,392,000,000$ & $947,704,683$ & 0.32 & 0.28 & 0.19 \\
2005 & $1,656,000,000$ & $1,112,781,141$ & 0.33 & 0.30 & 0.20 \\
2006 & $1,860,000,000$ & $1,220,962,407$ & 0.34 & 0.31 & 0.21 \\
2007 & $2,083,200,000$ & $1,392,559,430$ & 0.33 & 0.30 & 0.21 \\
2008 & $2,304,000,000$ & $1,547,618,593$ & 0.33 & 0.30 & 0.21 \\
\hline
\end{tabular}

\section{KESIMPULAN}

\section{Kesimpulan}

Berdasarkan penelitian selama 5 (lima) tahun dan analisis yang dilakukan, maka dapat ditarik suatu simpulan dari hasil penelitian ini, yaitu sebagai berikut:

1. Proses produksi cover protector ini berlangsung sesuai dengan tren yang terjadi pada penjualan motor Yamaha. Karena tanpa adanya biaya pemasaran dari pihak PT. Kandakawana Sakti sehingga biaya yang dikeluarkan menjadi efisien. Akan tetapi perusahaan tidak mampu meningkatkan penjualannya.

2. Karena tidak dapat menggunakan peningkatan penjualan sebagai cara untuk meningkatkan profitabilitasnya, maka perusahaan harus berupaya mengefisienkan biaya produksi untuk meningkatkan laba, karena dengan biaya produksi yang efisien akan mengurangi jumlah pengeluaran perusahaan tanpa perlu menaikan harga dan mengurangi kualitas.

3. Cara untuk mengefisienkan biaya dapat dengan penggantian beberapa bahan baku menjadi lebih efisien dan mengganti jam tenaga kerja lembur dengan penambahan tenaga kerja langsung dapat mengefisienkan biaya produksi. Yang dapat mempengaruhi HPP.

4. Dengan adanya penerapan efisiensi biaya tersebut juga dapat dilihat bahwa rasio GPM, OPM dan NPM sebagai rasio pengukur profitabilitasnya juga mengalami perbedaan. Jika diambil contoh pada tahun 2008 GPM perusahaan dengan biaya standar sebesar 0.32 dan GPM perusahaan yang menggunakan biaya setelah efisiensi sebesar 0.36 terdapat perbedaan GPM sebesar 0.04 dari penerapan kedua biaya tersebut. Pada tahun 2008 juga didapat OPM perusahaan dengan biaya standar sebesar 0.29 dan OPM perusahaan dengan efisiensi biaya sebesar 0.33. terdapat selisih yang sama dengan GPM yaitu sebesar 0.04. Pada tahun 2008 juga didapat NPM perusahaan dengan biaya standar sebesar 0.20 dan NPM perusahaan dengan efisiensi biaya sebesar 0.23 terdapat perbedaan sebesar 0.03 didalam kedua anggaran biaya tersebut.

5. Selain dari contoh pada tahun 2008 berdasarkan tren penjualan dan inflasi yang di alami perusahaan dapat di asumsikan adanya peningkatan penjualan dan kenaikan harga barang di tahun-tahun berikutnya. Selain berdasarkan asumsi tersebut dapat dilihat adanya peningkatan rasio profitabilitas yang di ukur melalui GPM, OPM dan NPM itu mengalami peningkatan yang cukup baik.

\section{Saran}

Dalam sebuah perusahaan seperti PT. Kandakawana sakti yaitu sebuah perusahaan jasa pengecatan, faktor biaya produksi menjadi faktor utama yang sangat menentukan kemajuan perusahaan. Karena apabila perusahaan tidak mampu menekan harga jasa yang diberikan dan mempertahankan kualitas tentunya mereka akan kehilangan konsumen. Maka dalam penetapan biaya standar untuk produksi hendaknya perusahaan melakukan suatu perencaan yang tepat dan baik yaitu pada biaya bahan 
Production Cost and Company's Profitability

168 baku dan biaya tenaga kerja langsung agar tercipta HPP yang lebih efektif sehingga perusahaan mempunyai daya saing akan jasa yang mereka tawarkan.

\section{DAFTAR PUSTAKA}

Carter, Willian K dan Milton F. Usry. 2004. Akuntansi Biaya. Edisi 13. Alih Bahasa: Krista. Salemba Empat, Jakarta.

Dewi astuti. 2004, Manajemen Keuangan Perusahaan, Penerbit Ghalia Indonesia, Jakarta

Effendy, M., Surya, TM., and Mubarak, MM. 2009. Pengaruh Struktur Modal Terhadap Resiko Keuangan Perusahaan. Jurnal Ilmiah Kesatuan (JIK), 11(1).

Erni Handayani, 2006, Efisiensi Biaya Operasional Guna Memperoleh Laba Lebih Optimal Pada CV. Sinar Jaya Mandiri, Bogor : Laporan Kerja Praktek

Garrison, Ray H., dan Eric W Noreen. 2000. Akuntansi Manajerial. Alib Bahasa : A. Totok Budisantoso. Salemba Empat, Jakarta.

Hansen, Don R., and Maryanne M. Mowen. 2003. Cost Management, Accounting and Control. Thomson South-Western, Ohio-USA.

J.Fred Weston, dan Thomas e. Copeland, Manajemen Keuangan, Binarupa Aksara Jakarta

Krismiaji. 2002. Dasar-dasar Akuntansi Manajemen. Cetakan I, UPP AMP YKPN, Yogyakarta.

Masiyah Kholmi dan Yuningsih, 2004. Akutansi Biaya. UMM Press. Malang.

Matz, Adolf, Milton F. Usry, dan Lawrence H Hammer. 1996. Akuntansi Biaya. Perencanaan dan Pengendalian. Alih Bahasa : Alfonsus Sirait dan Herman Wibowo. Erlangga, Jakarta.

Mulyadi. 1999. Akuntansi Biaya. Edisi 5. Aditya Media, Yogyakarta.

Pangi, 20V04. Analisis Laporan Keuangan Perusahaan Indonesia. Jakarta

Rayburn Gayle L., 1995. Cost Accounting. Sixth edition. Higher Education group.

Simamora, Henry. 2002. Akuntansi Manajemen. Edisi 2. Cetakan pertama, UPP AMP YPKN, Jakarta.

Simamora, Henry. 2002. Akuntansi Manajemen. Salemba Empat. Jakarta.

Siamangungsing, M. P. 1999. Pelajaran Akuntansi Biaya. Edisi 1. Cetakan 9, Karya Utama, Jakarta.

Suad Husnan dan Enny Pudjiastuti, 2004 Dasar-dasar Manajemen Keuangan, Penerbit UPP AMP YKPN, Yogyakart

Suad Husnan, 1996, Manajemen Keuangan, Penerbit BPFE, Yogyakart

S. Munawir 2002. Akuntansi Keuangan dan Manajemen, Edisi 1. BPFE, Yogyakarta.

Stoner et al 1992. Manajemen. Alih bahasa oleh Wilhemus dan B. Molan. Edisi ke - 4, cetakan ke - 1. Penerbit Intermedia. Jakarta.

Terry et al. 1992. Dasar-dasar Manajemen. Alih bahasa oleh GA. Ticoalu. Edisi bahasa Indonesia. Penerbit Intermedia. Jakarta.

Vernon, A. Musselman and John. H. Jackson. 1992. Pengantar Ekonomi Perusahaan. Edisi ke - 9, jilid 2. Penerbit Erlangga. Jakarta. 